\title{
IDENTIFIKASI SENYAWA KIMIA DAUN BAMBU SEGAR SEBAGAI BAHAN PENETRAL LIMBAH CAIR
}

\author{
Erni Romansyah ${ }^{2 *}$, Earlyna Sinthia Dewi ${ }^{2}$, Suhairin ${ }^{2}$, Muanah $^{2}$, Rosyid Ridho ${ }^{2}$ \\ ${ }^{1}$ Teknik Pertanian, Universitas Muhammadiyah Mataram, erniroman@gmail.com \\ ${ }^{2}$ Teknik Pertanian, Universitas Muhammadiyah Mataram
}

\begin{tabular}{l} 
INFO ARTIKEL \\
\hline RiwayatArtikel: \\
Diterima: 01-07-2019 \\
Disetujui: 11-08-2019
\end{tabular}

\section{Kata Kunci:}

Daun bambu

Senyawa kimia

Penetral limbah

Flavonoid

Alkaloid

\section{ABSTRAK}

\begin{abstract}
Abstrak: Daun bambu telah terbukti mampu menetralkan limbah cair hasil pertanian maupun limbah cair industry tahu berdasarkan penelitian sebelumnya yang pernah dilakukan. Akan tetapi belum diketahui senyawa kimia apa saja yang terkandung di dalam daun bambu sehingga mampu berperan sebagai penetral limbah cair. Tujuan penelitian ini adalah untuk mengidentifikasi senyawa kimia yang terkandung dalam daun bambu segar. Penelitian ini dilakukan secara eksperimental di laboratorium dengan mengamati beberapa parameter yaitu kandungan Flavonoid, Alkaloid, Saponin, dan Tanin. Hasil uji kuantitatif diperoleh berat Flavonoid untuk sampel daun bambu segar sebesar 5,5744 gram atau 5,57 \% berat sampel, Alkaloid sebesar 0,1421 gram atau 2,81 \% berat sampel, sedangkan hasil uji kualitatif daun bambu segar positif mengandung Saponin dan Tanin..
\end{abstract}

\begin{abstract}
Bamboo leaves have been proven to be able to neutralize agricultural wastewater and from tofu industrial wastewater based on previous research. However, it has not knows any chemical compounds contained in the leaves of bamboo so that it is able to neutralize wastewater. The purpose of this study is to research contained in fresh bamboo leaves. This research was carried out experimentally in laboratory by collecting several parameters, namely that is flavonoids, alkaloids, saponins, and tannins. Quantitative test results obtained from flavonoids for fresh bamboo leaf samples amounted to 5.5744 grams or $5.57 \%$ by weight of samples, alkaloids of 0.1421 grams or $2.81 \%$ by weight of samples, based on the test results of fresh bamboo fibers positively containing saponins and tannins
\end{abstract}

\section{A. LATAR BELAKANG}

Bambu merupakan tanaman jenis rumputrumputan dengan rongga dan ruas di batangnya. Salah satu keistimewaan bambu adalah tanaman dengan tingkat pertumbuhan paling cepat di dunia [1]. Tingginya tingkat pertumbuhan menyebabkan bambu sangat mudah ditemui di setiap daerah. Akan tetapi ada permasalahan yang muncul ketika bambu dipanen. Masalahnya adalah tingginya jumlah daun bambu yang harus dibuang sebagai limbah ke lingkungan.

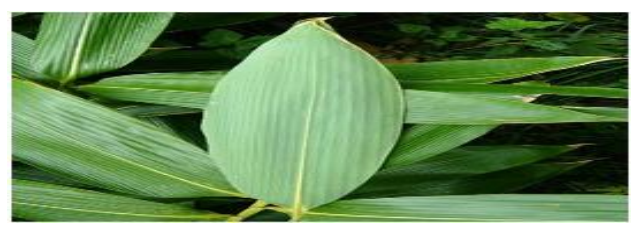

Gambar 1. Daun Bambu
Untuk mengatasi masalah tersebut maka pada penelitian terdahulu telah dilakukan upaya pemanfaatan daun bambu sebagai penetral limbah cair hasil pertanian dan memanfaatkan daun bambu sebagai penetral limbah cair industry tahu di Kota Mataram. Hasil penelitian tersebut menunjukkan bahwa penambahan daun bambu mampu menetralkan pH limbah [2]. Penelitian [3] dihasilkan bahwadaun bambu dapat menurunkan kandungan Nitrogen Total pada limbah cair tahu dengan perlakuan 50\%arang bambu : $50 \%$ daun bambu sebesar 38,13\% dari kandungan Nitrogen Total limbah cair tahu sebelum di filtrasi. Selain itu di Jepang, para petani memanfaatkan sersahan daun bambu segar untuk merendam limbah cair hasil pertanian sebelum dialirkan ke sungai.

Akan tetapi belum diketahui senyawa kimia apa saja yang terkandung di dalam daun bambu segar sehingga 
mampu berperan sebagai penetral limbah cair. Untuk itu dilakukanlah penelitian ini untuk mengidentifikasi senyawa kimia apa saja yang terkandung dalam daun bambu segar.

\section{B. METODE PENELITIAN}

Metode yang digunakan dalam penelitian ini adalah metode eksperimental di laboratorium.

\section{Parameter Penelitian}

Adapun parameter yang diamati dalam penelitian ini adalah uji kuantitatif Flavonoid dan Alkaloid, uji kualitatif Flavonoid, Alkaloid, Saponin dan Tanin. Pengujian dilakukan sebanyak 1 kali

\section{Pelaksanaan Penelitian}

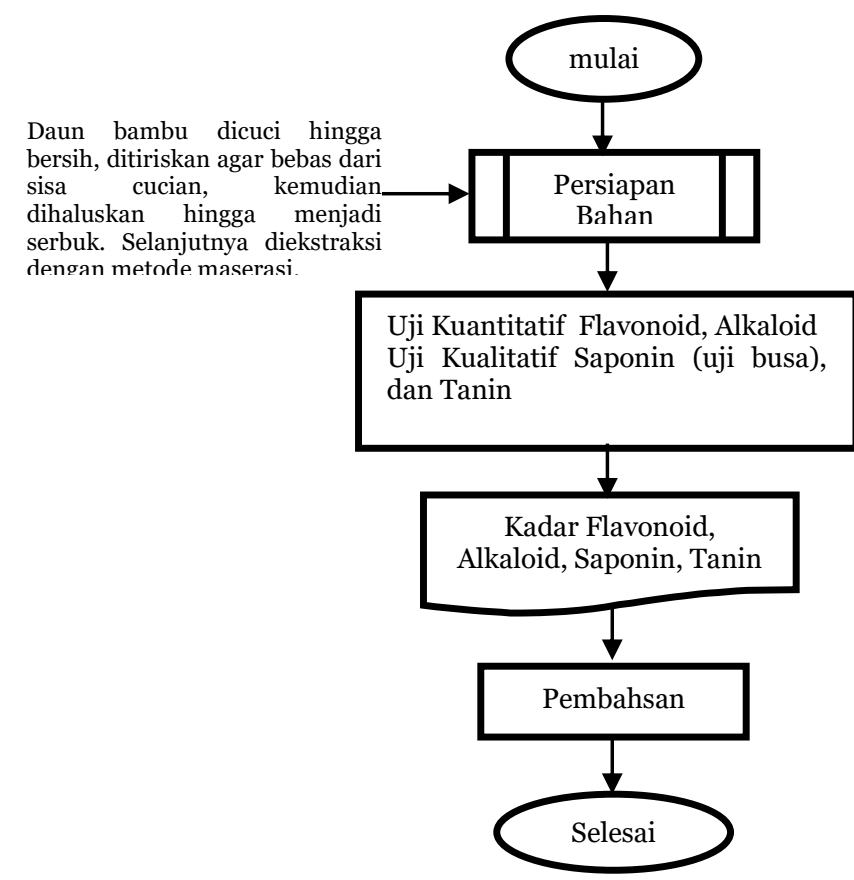

Gambar 2. Diagram Alir Pelaksanaan Penelitian

Tahapan yang dilakukan selama penelitian dan pengambilan data adalah sebagai berikut:

\section{Penyiapan bahan yang digunakan}

Daun bambu yang akan digunakan dicuci hingga bersih, ditiriskan agar bebas dari sisa cucian, kemudian dihaluskan hingga menjadi serbuk. Selanjutnya diekstraksi dengan metode maserasi.

\section{Uji Kuantitatif Flavonoid}

Ditimbang 100 gram serbuk sampel, dimaserasi dengan $100 \mathrm{ml}$ methanol 96\% pada suhu ruang selama 24 jam. Kemudian seluruh larutan disaring dan dipindahkan ke dalam cawan porselen. Lalu diuapkan hingga kering di atas penangas air kemudian ditimbang beratnya.

\section{Uji Kuantitatif Alkaloid}

Ditimbang 5 gram sampel ditambah $200 \mathrm{~mL}$ asam asetat $10 \%$ dalam metanol, lalu dimaserasi selama 24 jam dan disaring. Kemudian dipekatkan dengan memanaskannya pada penangas air hingga volume menjadi $1 / 4$ volume awalnya. Setelah itu ditambahkan $\mathrm{NH}_{4} \mathrm{OH}$ pekat tetes demi tetes sampai terbentuk endapan sempurna, lalu dicuci dengan $\mathrm{NH}_{4} \mathrm{OH}$ encer, lalu disaring dan dikeringkan lalu ditimbang beratnya.

\section{Uji Kualitatif Flavonoid}

Pengujian dilakukan dengan cara mengambil sampel sebanyak $2 \mathrm{ml}$ sampel daun bambu yang telah diekstraksi dengan pelarut metanol, kemudian dipanaskan kurang lebih 5 menit. Setelah dipanaskan ditambahkan dengan 0,1 gram logam $\mathrm{Mg}$ dan 5 tetes $\mathrm{HCl}$ pekat. Jika terbentuk larutan warna kuning jingga sampai merah, maka positif mengandung flavonoid

\section{Uji Kualitatif Alkaloid}

Sampel 3 gram ditambah $10 \mathrm{~mL}$ larutan 0,05 $\mathrm{N}$ amoniakloroform. Kemudian campuran dikocok selama satu menit, kemudian disaring kedalam tabung reaksi. Kepada filtrat tersebut ditambahkan $5 \mathrm{~mL} \mathrm{H} 2 \mathrm{SO}_{4}$ dan dikocok dengan teratur, didiamkan sampai terbentuk dua lapisan. Lapisan atas (fase air) dipisahkan dan diuji dengan dua pereaksi alkaloid yaitu pereaksi dragendorff dan pereaksi mayer. Hasil uji dinyatakan positif bila dengan pereaksi dragendorff terbentuk warna merah hingga jingga, dan endapan putih kekuningan dengan pereaksi mayer

\section{Uji Kualitatif Saponin (uji busa)}

Serbuk 1 gram dimasukkan kedalam tabung reaksi, ditambahkan $2 \mathrm{ml}$ air panas, didinginkan kemudian kocok kuat-kuat selama 10 detik, terbentuk buih lalu tambahkan 1 tetes asam klorida $2 \mathrm{~N}$, buih tidak hilang.

\section{Uji Tanin}

Ekstrak kental ditambahkan aquadest, didihkan selama 5 menit, ditambahkan dengan 5 tetes $\mathrm{FeCl}_{3}$ 1\%. Diamati perubahan warna yang terjadi. Terbentuknya warna biru tua atau hijau kehitaman menunjukkan adanya tanin.

\section{Bahan dan Alat}

Bahan yang diperlukan dalam kegiatan ini antara lain daun bambu segar, air, methanol 96\%, asam asetat, $\mathrm{NH}_{4} \mathrm{OH}$ pekat, $\mathrm{NH} 4 \mathrm{OH}$ encer, aquades, etanol $96 \%$, serbuk $\mathrm{Mg}, \mathrm{HCl}$, asam sulfat $2 \mathrm{~N}$, pereaksi dragendorff, pereaksi meyer, pereaksi wagner, dan $\mathrm{FeCl}_{3}$ 1\%.

Peralatan yang digunakan antara lain cawan porselen, penangas air, timbangan analitik, kertas saring, tabung reaksi, kompor listrik, erlenmeyer, gelas ukur, dan wadah pencuci. 


\section{HASIL DAN PEMBAHASAN}

\section{Uji Kuantitatifflavonoid}

Dalam uji kuantitatif flavonoid, sampel dimaserasi selama 24 jam dengan metanol $96 \%$. Digunakannya metanol $96 \%$ untuk maserasi karena metanol merupakan pelarut yang paling baik dan paling sering digunakan untuk ekstraksi flavonoid (Robinson, 1995).

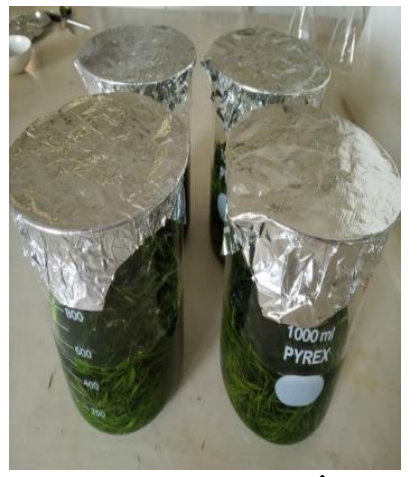

Proses Maserasi

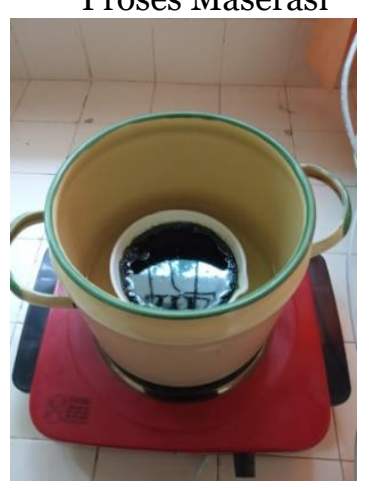

Proses penguapan

Flavonoid

Gambar 3. Proses Uji Kuantitatif Flavonoid

Ekstrak disaring dan diuapkan pelarutnya hingga kering, sehingga diperoleh padatan kering flavonoid. Padatan flavonoid tersebut kemudian ditimbang beratnya, diperoleh berat flavonoid sebesar 5,5744 gram atau 5,57\% berat sampel.

\section{Uji Kuantitatif alkaloid}

Sampel dimaserasi dengan asam asetat $10 \%$ dalam methanol, bertujuan untuk mengekstrak alkaloid yang bersifat basa. Fungsi dari penambahan $\mathrm{NH}_{4} \mathrm{OH}$ adalah untuk mengendapkan alkaloid.

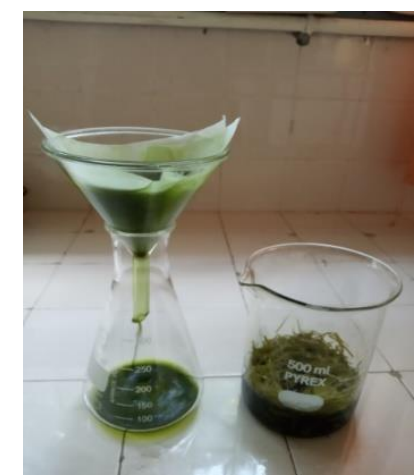

Penyaringan setelah maserasi

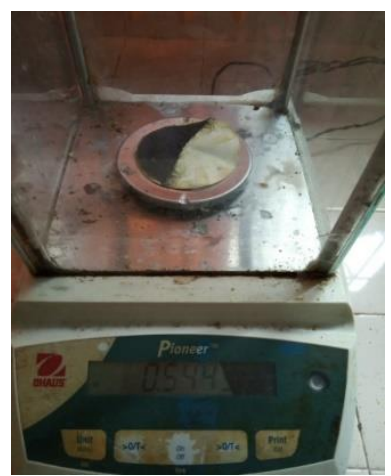

Berat kertas saring + sampel
Gambar 4. Proses Uji Kuantitatif Alkaloid

Endapan tersebut dipisahkan dengan cara disaring dan kemudian dikeringkan, setelah kering ditimbang beratnya. Dari hasil pengerjaan ini, diperoleh berat alkaloid untuk sampel daun bambu segar sebesar 0,1421 gram atau 2,81\% berat sampel.

\section{Uji Kualitatif Flavonoid}

Pada uji ini, menunjukkan hasil positif yaitu terbentuk warna merah.

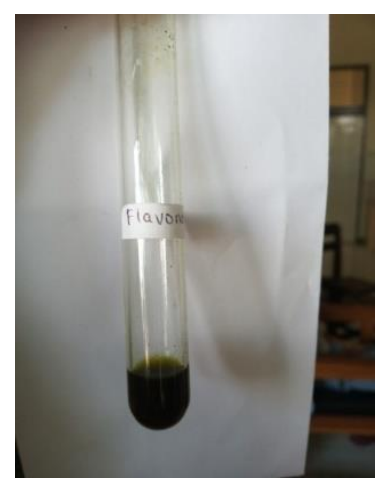

Sampel awal

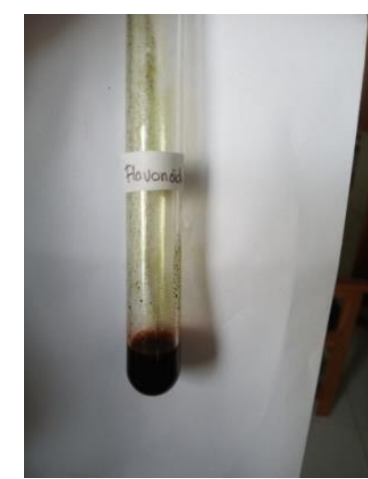

Sampel akhir
Gambar 5. Proses Uji Kualitatif Flavonoid

Pemanasan dilakukan karena sebagaian besar golongan flavonoid dapat larut dalam air panas. Tujuan penambahan logam $\mathrm{Mg}$ dan $\mathrm{HCl}$ adalah untuk mereduksi inti benzopiron yang terdapat dalam struktur flavonoid sehingga terbentuk garam flavilium berwarna merah atau jingga.

\section{Uji Kualitatif Alkaloid}

Sampel diekstrak dengan N-ammoniakloroform kemudian disaring dan ditambahkan asam sulfat pekat yang tujuannya untuk menggaramkan alkaloid. Setelah itu dikocok sehingga terbentuk dua lapisan. 


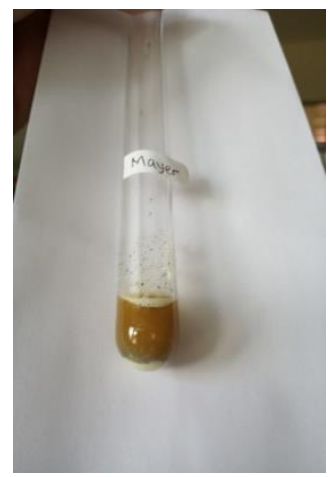

Pereaksi Mayer

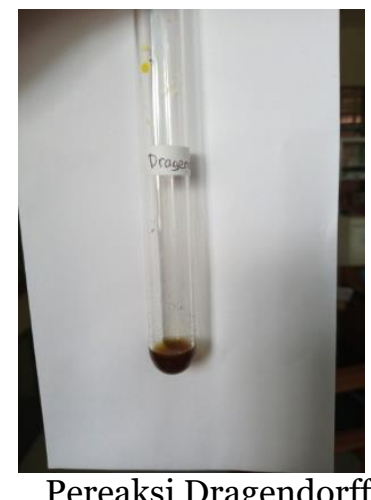

Pereaksi Dragendorff
Gambar 6. Proses Uji Kualitatif Flavonoid

Lapisan atas yang merupakan fase air diuji dengan pereaksi Dragendorff, Mayer dan Wagner. Dari ketiga uji ini menunjukan hasil yang positif, yaitu terbentuk endapan putih untuk uji Mayer dan endapan cokelat untuk uji Wagner.

\section{Uji kualitatif Saponin}

Pada identifikasi saponin sampel di uji dengan ditambahkan air dan $\mathrm{HCl} 1 \mathrm{~N}$ lalu di kocok kuat.

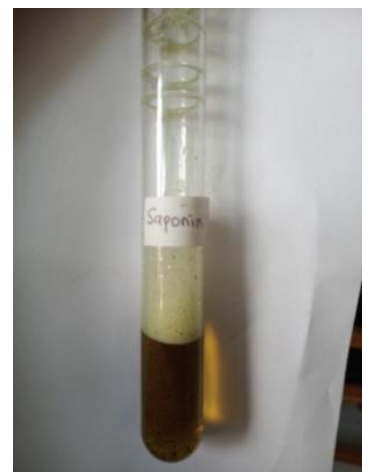

Gambar 7. Proses Uji Kualitatif Saponin

Terbentuk Buih

Hasil menunjukan positif karena larutan sampel terbentuk buih atau busa. Busa yang terbentuk tetap stabil selama \pm 5 menit.

\section{Uji kualitatif Tanin}

Uji fitokimia dengan menggunakan $\mathrm{FeCl}_{3}$ digunakan untuk menentukan apakah sampel mengandung gugus fenol.

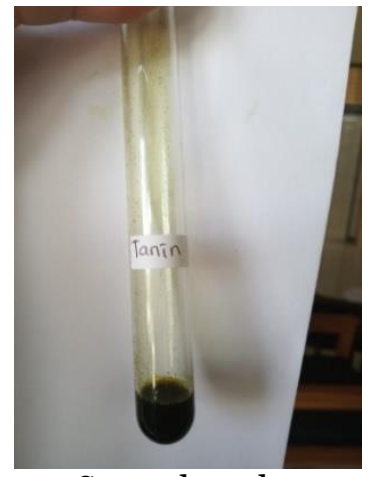

Sampel awal

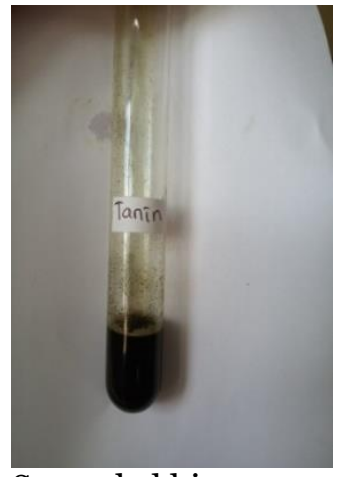

Sampel akhir
Gambar 8. Proses Uji Kualitatif Tanin

Adanya gugus fenol ditunjukkan dengan warna hijau kehitaman atau biru tua setelah ditambahkan dengan $\mathrm{FeCl}_{3}$, sehingga apabila uji fitokimia dengan $\mathrm{FeCl}_{3}$ memberikan hasil positif dimungkinkan dalam sampel terdapat senyawa tanin karena tanin merupakan senyawa polifenol.

Berdasarkan uraian hasil penelitian diatas, telah berhasil diidentifikasi senyawa utama penyusun daun bambu seperti flavonoid, alkaloid, saponin, dan tanin. Menurut Rahayu, Sri et al., (2011); Ogunjinmi et al., (2009) dalam [4] daun bambu memiliki kandungan flavonoid cukup tinggi.

Sedangkan, [5] dan El-Rokiek (2010) menyatakan bahwa flavonoid merupakan turunan dari senyawa fenol bersifat alelokimia [6] menyatakan bahwa senyawa fenol dapat menyebabkan penurunan permeabilitas membran sel. [7] menyebutkan bahwa terdapat hubungan yang erat antara kandungan flavonoid terhadap aktivitas antioksidan. Semakin tinggi kandungan flavonoid maka aktivitas antioksidannya juga semakin tinggi.

Flavonoid merupakan senyawa golongan polifenol yang terdiri dari 15 atom karbon yang terdapat dalam inti dasarnya, flavonoid tersusun dalam konfigurasi C6-C3-C6 [8]. Lebih dari 4.00o flavonoid yang sejauh telah teridentifikasi. Dalam tumbuhan, flavonoid biasanya terikat pada gula sebagai senyawa glikosida dan aglikon flavonoid yang bisa saja terdapat dalam satu tumbuhan berupa kombinasi glikosida [9]. Aglikon flavonoid sesungguhnya adalah polifenol dan oleh karena itu Aglikon flavonoid mempunyai sifat kimia seperti senyawa fenol, yaitu bersifat agak asam sehingga dapat larut dalam basa. Sifatnya yang dapat larut dalam basa ini mengakibatkan limbah cair tahu maupun limbah cair hasil pertanian yang bersifat asam dapat ditingkatkan $\mathrm{pH}$ nya menjadi netral. Hal itulah yang menyebabkan daun bambu dapat berperan sebagai peetral limbah cair. Tetapi bila dibiarkan dalam larutan basa, dan di samping itu terdapat oksigen, banyak yang akan terurai [8]. Sehingga hasil pengukuran BOD dan COD pada limbah cair setelah difiltrasi menjadi sangat rendah.

Dalam daun bambu juga positif mengandung Senyawa Tanin. Dalam kedokteran, terutama di Asia (Jepang dan Jepang) tanin digunakan sebagai astringen, melawan diare, sebagai diuretik, melawan lambung dan tumor duodenum [10], dan sebagai antiinflamasi, antiseptik, antioksidan dan hemostatik obat-obatan [11]. Tanin digunakan dalam industri zat warna sebagai kaustik untuk pewarna kationik (pewarna tanin). Dalam industri makanan tanin digunakan untuk membersihkan anggur, bir, dan jus buah [12].

\section{SIMPULAN}

Telah berhasil diidentifikasi senyawa utama penyusun daun bambu seperti flavonoid, alkaloid, saponin, dan tanin. Hasil uji kuantitatif diperoleh berat Flavonoid untuk sampel daun bambu segar sebesar 5,5744 gram atau 5,57 \% berat sampel, Alkaloid sebesar 0,1421 gram atau 2,81\% berat 
sampel, sedangkan hasil uji kualitatif daun bambu segar positif mengandung Saponin dan Tanin.

\section{UCAPAN TERIMA KASIH}

Penulis mengucapkan terima kasih kepada LPPM Universitas Muhammadiyah Mataram selaku pemberi dana melalui Hibah Kompetitif Dosen Tahun 2019.

\section{DAFTAR RUJUKAN}

[1] Gerbono, Anton dan Abbas Siregar Djarirah, 2013. Aneka Anyaman Bambu. Kanisius, Yogyakarta.

[2] Romansyah, Erni, Muliatiningsih, Dina Soes Putri, 2018. Pengaruh Pemberian Daun bambu dan Arang Bambu pada Pengelolaan Limbah Cair Tahu. Jurnal Agrotek UMMat 5(2), 86-79, 2018.

[3] Muliatiningsih, Erni Romansyah, Karyanik, 2018. Pemanfaatan Limbah Bambu sebagai Bahan Filtrasi untuk Mengurangi Kandungan Nitrogen Total dalam Air Buangan Limbah Tahu. Vol 5, No. 2, Agustus, 2018.

[4] Sujarwo, WB, Ketut Arinasa, I, \& Nyoman, PI, 2010, 'Potensi Bambu Tali (Gigantochloa apus J.A \& j.H. Schult Kurz) Sebagai Obat di Bali', Bul. Littro, vol. 21, no. 2, hal. 134.

[5] El-Rokiek, G, Kowthar, R, El-Masry, Rafet \& K. Nadia, Messiha, 2010, "The Allelopathic Effect of Mango Leaves on the Growth \& Propagative Capacity of Purple Nutsedge (Cyperus rotundus L.)", Journal American Research, vol. 6, no. 3, hal 151-159

[6] Sastroutomo, 1990. Ekologi Gulma, Gramedia Pustaka Utama, Jakarta.

[7] Verdiana, Melia, I Wayan Rai Widarta,I Dewa Gede Mayun Permana, 2018. "Pengaruh Jenis Pelarut pada Ekstraksi Menggunakan Gelombang Ultrasonik Terhadap Aktivitas Antioksidan Kulit Buah Lemon", Jurnal Ilmu dan Teknologi Pangan, Vol 7, No. 4, h. 213222, Desember 2018, ISSN: 2527-8010.

[8] Markham, K.R. (1988). Cara Mengidentifikasi Flavonoida. Padmawinata K, penerjemah; Nisolihin S, editor. Pnerbit ITB. Bandung. Ternerjemah dari: Techniques of Flavonoid Identification.

[9] Harbourne, J.B., (1987), Metode Fitokimia Penentuan Cara Moderen Menganalisa Tumbuhan, Terbitan kedua, Penerbit ITB Bandung, Bandung.

[10] De Bruyne T, Pieters L, Deelstra H, Vlietinck A. Condensed vegetables tannins: biodiversity in structure and biological activities. Biochemical System Ecology, 1999; 27: 445-59. 40.

[11] Dolara P, Luceri C, De Filippo C, Femia AP, Giovannelli L, Carderni G, Cecchini C, Silvi S, Orpianesi C, Cresci A. Red wine polyphenols influence carcinogenesis, intestinal microflora, oxidative damage and gene expression profiles of colonic mucosa in F344 rats. Mutation Research, 2005; 591: 237-46

[12] Saxena, Mamta, Jyoti Saxena, Rajeev Nema, Dharmendra Singh and Abhishek Gupta, 2013. Phytochemistry of Medicinal Plants. Journal of
Pharmacognosy and Phytochemistry, Volume 1 Issue 6, Page 168-182, ISSN 2278-4136, ZDB-Number: 2668735-5 IC Journal No: 8192 Online Available at www.phytojournal.com. 